\title{
Dampak Strategi Problem Posing terhadap Critical Literacy Siswa SLB
}

\author{
Anisa Sholihah ${ }^{1}$ dan Ani Rusilowati ${ }^{2}$ \\ Jurusan Fisika, FMIPA, Universitas Negeri Semarang \\ 1) anisasholihah898@gmail.com \\ ${ }^{2)}$ rusilowati@mail.unnes.ac.id
}

\begin{abstract}
Abstrak
Tujuan penelitian ini yaitu untuk mengetahui dampak strategi problem posing terhadapcritical literacysiswa sekolah luar biasa (SLB). Subjek Penelitian kualitatif ini menggunakan Single Subject Research Design yaitu satu siswa SLBtipe D(Tunadaksa) kelas VII SLB Purwosari, Kudus. Penelitian ini terdiri atas dua fase yaitu: (1) Fase Baseline "A", observasi atau melakukan pengukuran no intervation pada Prosen belajar mengajar (PBM) oleh guru kelas di dalam kelas integrasi untuk melihat keadaan/perilaku awal; (2) Fase Intervention "B", eksperimen atau pemberian perlakuan hanya terhadap subjek penelitian untuk melihat perubahan yang terjadi. Analisis data yang digunakan yaitu analisis visual dan diskriptif.
\end{abstract}

Kata kunci: Problem Posing, Critical Literacy, SLB

\section{PENDAHULUAN}

Indonesia memberlakukan Hak Anak melalui Keputusan Presiden No. 36/1990 tertanggal 5 Oktober 1990 (Delphie, 2009: 13). Hal ini menjadi angin segar bagi anak berkebutuhan khusus (ABK) untuk melangsungkan hidupnya seperti orang lain. Perubahan ini tentu berpengaruh pada keadaan sosial ABK di masyarakat. Karena 80 persen ABK menghabiskan lebih dari setengah harinya tanpa kelas regular (Bennet, 2009). Data Kementerian Sosial RI tahun 2008 menunjukkan total ABK sebanyak 1.540.184 anak, dan diprediksi bahwa sensus nasional tahun 2010, angka ABK (5-18 tahun) sebesar 21,42\% dari jumlah ABK dengan berbagai kekurangan/kecacatan, yaitu sebesar 330.764 anak (dalam Mudjito, Harizal, dan Elfindri, 2013).

Dunia pendidikan mempunyai peranan penting bagi ABK. Sekolah Luar Biasa merupakan sekolah khusus yang menampung berbagai tipe ABK. ABK dikategorikan menjadi lima kategori, yaitu kelakuan, komunikasi, intelegensi, ketidakmampuan fisik, dan kombinasi tersebut. Di sekolah diharapkan mereka mendapatkan kesempatan untuk mengenal dunia dan lingkungannya.Namun, hasil monitoring dan evaluasi Direktorat Pembinaan Pendidikan Khusus dan Layanan khusus Pendidikan Dasar Kementerian Pendidikan Nasional tahun 2010 ditemukan bahwa kinerja guru inklusi pada sekolah masih rendah (Mudjito, Harizal, dan Elfindri , 2013). Ibu Dwi, guru kelas VII SLB PorwosariKudus, mengungkapkan bahwa guru dalam memberikan materi yang diajarkan bereferensi dari internet karena belum ada buku panduan bagi siswa SLB. Dan alat peraga yang digunakan di 
SLB Porwosari, Kudus masih terbatas meskipun tipe siswa SLB di sekolah tersebut bermacam-macam.

Penemuan Direktorat Pembinaan Pendidikan Khusus dan Layanan khusus Pendidikan Dasar Kementerian Pendidikan Nasional tahun 2010 menunjukkan perlunya peningkatan kinerja guru inklusi untuk mengembangkan potensi ABK. Suatu pola gerak yang bervarisi diyakini dapat meningkatkan potensi $\mathrm{ABK}$ dalam kegiatan pembelajaran, berkaitan dengan pembentukan fisik, emosi, sosialisasi, dan daya nalar (Delphie, 2009). Critical literacy di kelas tuna rungu dewasa dapat meningkatkan kemampuan membaca dan menulis bahasa Inggris dan membantu mereka terhubung dengan lingkungan sekitar (Enns, 2009). Tantangan menerapkan strategi pembelajaran yang tepat untuk pengembangan kemampuan critical literacy bagisiswa denganlearning disabilities bermanfaat untuk meningkatkankemampuan critical literacy (Knight, 2009). Pentingnya guru untuk mendorong siswa mengembangkan pelajaran,menerapkan model yang kreatif dan efektif, dapat menaikkan critical literacy dalam Matematika dan IPA (Darvin, 2007). Pengembangan literasi matematika dan IPA ini juga diperlukan oleh ABK.

Berdasarkan latar belakang tersebut, permasalahan yang diangkat dalam penelitian ini adalah bagaimana dampak strategi problem posing terhadap critical literacy siswa SLB.

\section{METODE PENELITIAN}

Penelitian ini menggunakan metode kualitatif dengan Single Subject Research Design (SSRD).SSRD involves studying a single individual or system by taking repeated measurements of 1 or more dependent variables and systematically applying \& sometimes, withdrawing or varying the independent variable (Bloom \& Fischer, 1982dalam Bill Miller). SSRD membahas individual tunggal atau sistem dengan pengukuran berulang dari satu atau lebih variabel terikat dan penerapan yang sistematis yang terkadang menarik atau bermacammacam variabel bebas/independen.

Teknik pengambilan data dengan cara observasi partisipatif. Penelitian kualitatif memperlakukan data sebagai sesuatu yang bermakna intrinsik, dengan demikian data bersifat 'lunak', tidak sempurna, imaterial, kadang kala kabur dan seorang peneliti kualitatif tidak akan pernah mampu mengungkapkan semuanya secara sempurna. Namun demikian, data penelitian bersifat empiris, terdiri atas dokumentasi, ragam peristiwa, rekaman setiap ucapan, kata dan gesture dari objek kajian, tingkah laku yang spesifik, dokumen-dokumen tertulis, serta berbagai imajinasi visual yang ada dalam sebuah fenomena sosial (Newman, 1997 dalam Somantri, 2005). 
Penelitian ini menggunakandesain A-B yang merupakan desain dasar dari penelitian eksperimen subyek tunggal. Prosedur desain ini disusun atas dasarlogika baseline (baseline logic). Pada penelitian ini dilakukan pengulangan pengukuran perilaku atau target behavior, pada sekurang-kurangnyadua kondisi yaitu kondisi baseline (A) dan kondisi intervensi (B). Oleh karena itu, dalam melakukan penelitian dengan desain kasus tunggal akan selalu ada pengukuran targetbehavior pada fase baseline dan pengulangannya pada sekurang-kurangnya satu fase intervensi (Hasselt dan Hersen, 1981 dalam Sunanto, Takeuchi, dan Nakata, 2005).

Prosedur utama yang ditempuh dalam disain A-B meliputi pengukuran target behavior pada fase baseline dan setelah trend dan level datanya stabil kemudian intervensi mulai diberikan. Selama fase intervensi target behavior secara kontinyu dilakukan pengukuran sampai mencapai data yang stabil (Tawney dan Gast, 1984 dalam Sunanto, Takeuchi, dan Nakata, 2005). Jika terjadi perubahan target behavior pada fase intervensi setelah dibandingkan dengan baseline, diasumsikan bahwa perubahan tersebut karena adanya pengaruh dari variabel independen atau intervensi.

Penelitian ini terdapat dua fase yaitu: (1) Fase Baseline "A", peneliti melakukan observasi atau melakukan pengukuran dengan no intervation pada PBM oleh guru kelas di dalam kelas integrasi untuk melihat keadaan/perilaku awal; (2) Fase Intervation "B”, peneliti melakukan eksperimen atau memberikan perlakuanhanya terhadap subjek penelitian untuk melihat perubahan yang terjadi.

Teknik pengumpulan data dalam penelitian ini sebagai berikut: (1) Observasi partisipasi pasif, peneliti berada di tempat kegiatan PBM oleh guru kelas tetapi tidak ikut terlibat dalam kegiatan tersebut, (2) Wawancara, dan (3) Dokumen oleh peneliti atau dari subjek penelitian.

Pemeriksaan keabsahan data menggunakan Triangulasi. Triangulasi diartikan sebagai teknik pengumpulan data yang bersifat menggabungkan dari berbagai teknik pengumpulan data dan sumber data yang telah ada. Peneliti mengumpulkan data sekaligus menguji kredibilitas data, yaitu mengecek kredibilitas data dengan berbagai teknik pengumpulan data (Sugiyono, 2010: 330).

Pada penelitian ini menggunakan Triangulasi, yaitu teknik yang digunakan dalam pengumpulan data berbeda-beda yang berasal dari hanya subjek tunggal (individual). 


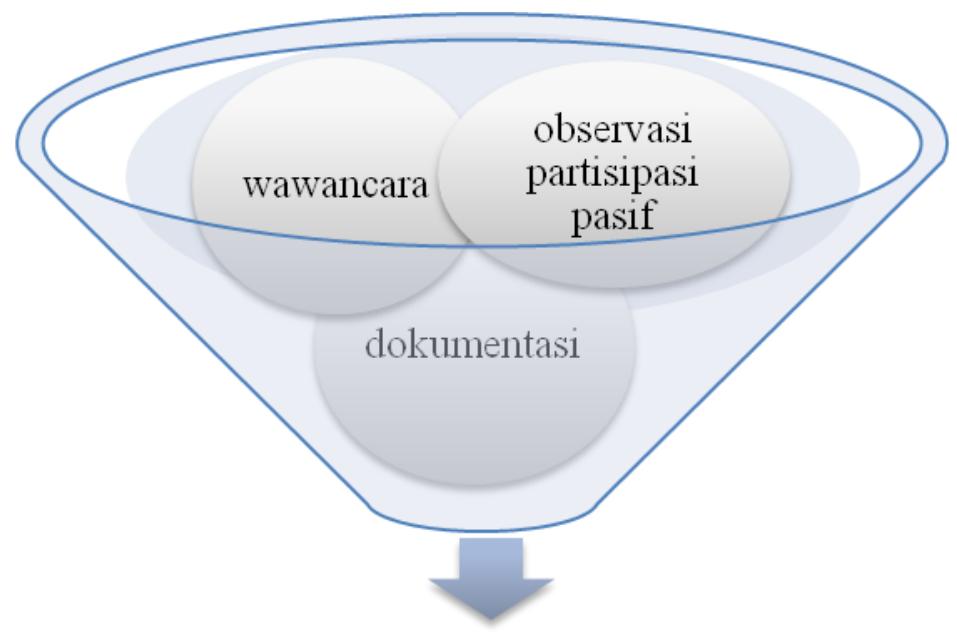

Data subjek tunggal Siswa SLB tipe D

Gambar1.Triangulasi teknik pada $S S R D$

Penelitian dengan kasus tunggal penggunaan statistik yang komplek tidak dilakukan tetapi lebih banyak menggunakan statistik deskriptif yang sederhana. Teknik analisis data yang dilakukan dalam penelitian ini yaitu analisis visual dan deskripstif. Langkah-langkah analisis data yaitu: (1) pembuatan grafik; (2) penggunaan statistik deskriptif; dan (3) analisis visual.

Komponen-komponen analisis visual meliputi komponen analisis visual dalam kondisi dan komponen analisis visual antarkondisi. Komponen analisis visual dalam kondisi terdiri atas: (1) panjang kondisi yaitu tiga atau lima poin pengukuran kondisi yang digunakan untuk menunjukkan kestabilan; (2) estimasi kecenderungan arah yaitu gambaran perilaku subyek yang sedang diteliti, dapat meningkat, mendatar, bahkan menurun; (3) kecenderungan stabilitas; (4) jejak data; (6) level stabilitas dan rentang; dan (7) perubahan level. Komponen analisis visual antarkondisi yaitu menganalisis perubahan antarkondisi, dengan syarat kondisi sebelum dianalisis sudah stabil.Komponen analisis visual antarkondisi terdiri atas: (1) jumlah variabel; (2) perubahan arah dan efeknya; (3) perubahan stabilitas; (4) perubahan level; dan (5) persentase overlap.

\section{HASIL DAN PEMBAHASAN}

Penelitian ini baru sampai pada fase baseline (A). Data-data penting pada fase A digambarkan sebagai berikut: (1) subyek penelitian adalah siswa laki-laki, berinisial NMH, yang dilahirkan tanggal 18 Mei 1999 setelah masa kehamilan sembilan bulan lebih melalui 
persalinan biasa; (2) Ketika di dalam kandungan, ibu dari NMH sehat; (3) NMH mempunyai fisik yang lemah dan cepat capek; (4) tidak ada keluarga yang memiliki riwayat yang sama seperti NMH; (5) Karakteristik psikologis dan fisik NMH dapat dilihat Tabel 1, 2; (6) Kondisi kelas dapat dilihat pada Gambar 2.

Tabel 1. Karakteristik Mental/Psikologis

\begin{tabular}{ll}
\hline Mengerti ucapan dan perintah orang lain & Dapat \\
Membentuk kalimat sederhana & Dapat \\
Menyebut angka & Dapat \\
Banyak tidak bergerak atau tidak tenang & Tidak \\
Makan sendiri & Dapat \\
Mandi sendiri & Dapat \\
Sering mengalami gerakan yang aneh & Tidak \\
\hline
\end{tabular}

Tabel 2. Karakteristik Fisik

\begin{tabular}{lc}
\hline Berat/ tinggi badan & $38 \mathrm{Kg}, 150 \mathrm{~cm}$ \\
Memegang pensil & Dapat \\
Keadaan penglihatan & Sedang \\
Membedakan rasa (asin, manis, pedas, asam) & Dapat \\
Membedakan warna & Dapat \\
\hline
\end{tabular}

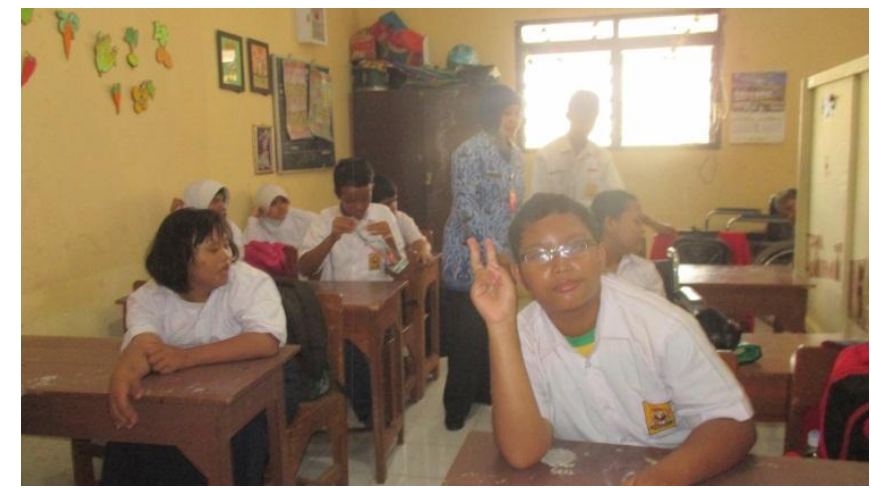

Gambar 2. Suasana Kelas VII (subjek penelitianberada dalam kelas integrasi)

Istilah yang berkaitan proses pembelajaran $\mathrm{ABK}$ antara lain normalisation, integration, mainstreaming, dan inclusion. (1) Normalisation merupakan konsep hukum sosial yang menyatakan bahwa normalisation merupakan dasar kebijakan dalam pendidikan khusus sebagai sistem sekolah. Prinsip-prinsip normalisation menyarankan bahwa semua 
peserta didik harus mempunyai kesempatan untuk dapat bersekolah pada sekolah yang dekat dengannya atau sekolah yang sesuai dengan keinginan orang tua mereka yang mana mereka berhak menentukan secara bebas sekolah mana yang diinginkan (Delphie, 2009). Hal ini berarti ABK dapat bersekolah di sekolah yang dekat dari tempat tinggalnya atau sekolah yang dipilih oleh orang tuanya. Karena, SLB jumlahnya sedikit dan biasanya berada di kota-kota besar. Di kabupaten Kudus hanya terdapat tiga SLB. Jenjang atau tinngkat pendidikan SLB di Kudus sampai saat ini terbatas hingga tingkat Sekolah Menengah Pertama. (2) Integration atau integrasi merupakan suatu proses pemindahan peserta didik dalam setiap pendidikan yang mengarah pada upaya meminimalkan segregasi. Suatu keadaan dapat memungkinkan adanya segregasi atau pemisahan peserta didik. Integrasimembatasi adanya pemisahan terhadap siswa ABK meskipun jenis-jenis ABK bermacam-macam. Hal positif yang dapat dilihat dalam integrasi yaitu jalinan interaksi dan komunikasi antara ABK tidak dipersempit. (3) Mainstreaming adalah suatu rangkaian jenis-jenis layanan pendidikan bagi siswa-siswa yang memiliki hambatan, pengurangan jumlah anak-anak 'yang ditarik keluar' dari kelaskelas regular dan penambahan ketepatan-ketepatan bagi layanan pendidikan di dalam kelaskelas regular daripada di luar kelas-kelas tersebut (Berry, 1972 dalam Smith, 2013). Mainstreaming menyarankan kelengkapan sarana dan prasarana yang dibutuhkan dalam suatu kelas. Jika hal ini dipenuhi, maka penarikan keluar ke tempat atau area yang dibutuhkan ABK tidak menjadi pilihan lagi. (4) Konsep inklusi berdasarkan atas gagasan bahwa sekolah regular harus menyediakan lingkungan belajar bagi seluruh peserta didik sesuai dengan kebutuhannya, apapun tingkat kemampuan ataupun kelainannya. Inklusi biasanya memberikan penempatan belajar ke arah regular tanpa menghiraukan tingkat atau tipe kelainannya (Brown, 1995 dalam Delphie, 2009: 16).Siswa dalam setting inclusive menunjukkan performa lebih baik pada pengukuran akademik sebaik pengukuran pada kompetensi sosial(Bennet, 2009). Penelitian ini telah didesain sesuai dengan normalisation, integration, mainstreaming, dan inclusion. Pada fase A, NMH tidak perlu keluar dari kelas integrasi untuk mendapatkan kestabilan kondisi.

Penelitian pada fase intervensi (B) sedang berlangsung. Pada fase B NMH diberikan intervensi berupa strategi problem posing yang nantinya akan dianalisis dampaknya terhadap critical literacy $\mathrm{NMH}$.

Problem posingmerupakan strategi dalam menumbuhkan critical literacy menggunakan teks narasi dan informatif, hypertext, multi media, dan conversetion atau percakapan. Setelah siswa membaca teks atau menonton video, mendiskusikan situasi yang dianalisis, siswa dapat menumbuhkan critical literacy melalui pembuatan pertanyaan-pertanyaan. Sintaks 
pembelajaran dengan problem posing terdiri atas empat fase, yaitu: (1) engaging student thinking, (2) guiding student thinking, (3) extending student thinking, dan (4) reflection (DeVoogd \& McLaughlin, 2004).

Sejak tahun 1990an, teori critical literacy telah diuraikan dalam teori emansipatoris pembelajaran (Freire dan Brannon, 1993 dalam Bishop, 2014). Critical Literacy dibangun pada pengembangan personal, sosial politik, ekonomi, dan identitas batas intelektual (Bishop, 2014). Bishop mengidentifikasi tiga bentuk praktek pendidikan bahwa Critical Literacy yaitu pendidikan liberal, pluralisme, praktek transformatif. Pendekatan Critical Literacy untuk mengajar tampaknya akan mendapatkan momentum di sekolah di banyak disiplin ilmu (Wallowitz et al., 2011). Pengembangan pemahaman tentang IPA dan epistemologi pengetahuan saintifik menganjurkan bahwa siswa harus terikat pada orientasi epistemologikal mereka sendiri dan percaya pada pembuktian saintifik, logika, dan justifikasinya.

Proses interversi dapat dilihat pada Gambar 3.

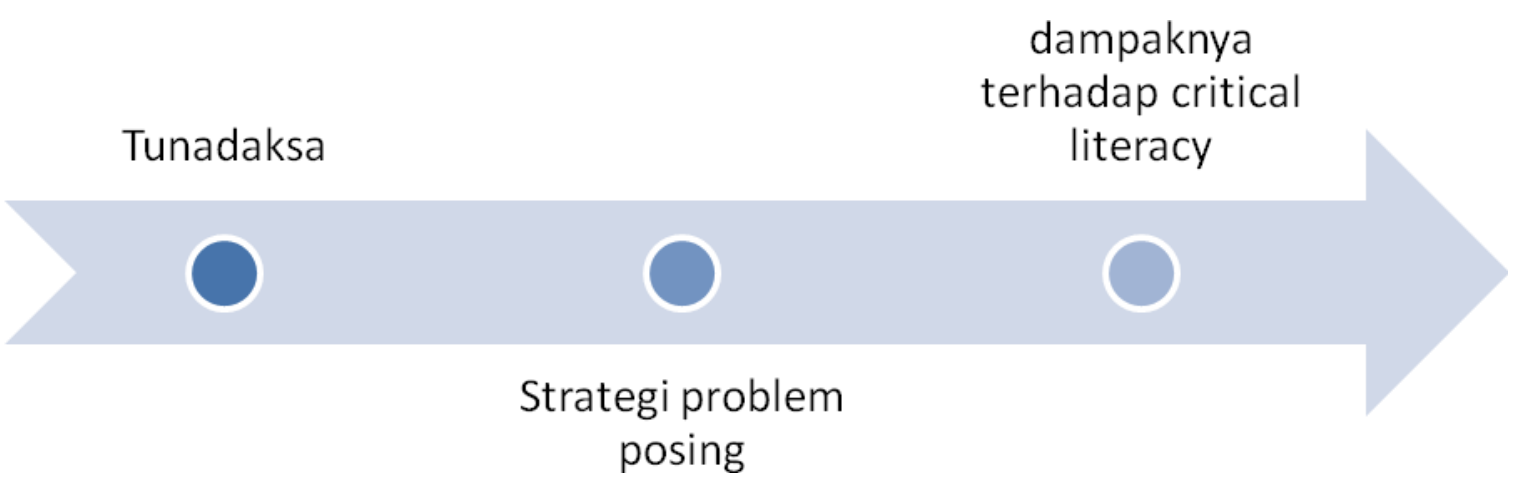

Gambar 3. Proses intervensi

\section{KESIMPULAN}

Secara hipotetik, kemampuan critical literacy siswa tunadaksa dapat ditumbuhkan menggunakan strategi problem posing. Mengingat jumlah siswa ABK dalam setiap SLB tidak terlalu banyak, maka penelitian dapat dilakukan secara kualitatif, bahkan dengan subjek tunggal. Desain penelitian yang dapat digunakan adalah single subject research design tipe A-B. A adalah fase baseline tanpa intervensi, dan B adalah fase intervensi. Data fase baseline dapat diperoleh dari PBM guru di kelas. Hasil penelitian menunjukkan bahwa critical litreracy subjek penelitian masih rendah. Hal ini karena guru memang tidak membiasakan 
siswa untuk melakukan critical literacy terhadap bacaan yang dipelajari. Data intervensi diambil secara berulang hingga diperoleh kondisi yang stabil. Strategi problem posing ini diharapkan dapat diterapkan juga pada ABK dengan ketunaan yang berbeda.

\section{DAFTAR PUSTAKA}

Bennet, S. 2009. Including Students with Exceptionalities. ISSN 19131100 What Works? Research Into Practice at www.edu.gov.on.ca/eng/literacynumeracy /inspire/research/whatWorks.html (diakses tanggal 25 Juli 2016).

Bishop, E. 2014. Critical Literacy Bringing Theory to Praxis. Journal of Curriculum Theorizing Vol. 30 No.1. (diakses tanggal 25 Juli 20116)

Darvin, J. 2007. Teaching Critical Literacy Principles to Math and Science Educators.Teaching Education, 18:3, 245-256.http://dx.doi.org/10.1080 /10476210701535055 (diakses tanggal 16 Agustus 2016).

Delphie, B. 2009. Pembelajaran Anak Berkebutuhan Khusus dalam Setting Pendidikan Inklusi. Yogyakarta: Intan Sejati Klaten.

DeVoogd, G. L. dan McLaughlin, M. 2004. Theory and Practice Critical Literacy: Enhancing Students' Comprehension of Text. New York: Scholastic Inc. (diakses tanggal 25 Juli 2016)

Knight, B. A. 2009. Teaching Critical Literacy Skills to Students with Learning Disabilities. Australian Journal of Learning Disabilities Volume 3, Issue 4. (diakses tanggal 25 Juli 2016).

Miller, B. Single Subject Research Design (SSRD). SSRD Workshop, UBC School of Rehab Sciences, VCHA OT Research Scientist. http://www.vchri.ca/i/pdf/SingleSubjectResearch.pdf (diakses tanggal 2 September 2016)

Mudjito, Harizal, dan Elfindri. 2013. Pendidikan Inklusif. Jakarta: Baduose Media.

Smith, J. D. 2013. Sekolah Inklusif: Konsep dan Penerapan Pembelajaraan. Diterjemahkan dari J. David Smith, Inclusion, School for All Student (Wardsworth Publishing Company, 1998). Bandung: Nuansa Cendekia.

Somantri, Gumilar Rusliwa. 2005. Memahami Metode Kualitatif. Makara, Sosial Humaniora, Vol. 9 , No. 2. http://hubsasia.ui.ac.id/index.php/hubsasia/article/viewFile/122/110(diakses tanggal 25 Juli 2016).

Sugiyono. 2010. Metode Penelitian Pendidikan: Pendekatan Kuantitatif, Kualitatif, dan $R \& D$. Bandung: Alfabeta.

Sunanto, J., Takeuchi, K., dan Nakata, H. 2005. Pengantar Penelitian dengan Subjek Tunggal. Center of Research on International Cooperation in Educational Development(CRICED) University of Tsukuba (diakses tanggal 10 September 2016).

The State of Queensland. 2015. Physical Disability. https://www.qld.gov.au/disability/community/physical-disability/ (diakses tanggal 23 September 2016).

Wallowitz, L., de Freitas, M. E., Hogan, T. dan Linne, R. 2011. Critical Literacy in Math and Science. Proceedings of epiSTEME 4 (diakses tanggal 25 Juli 2016). 